\title{
LAW AND DEVELOPMENT: THE KOREAN EXPERIENCE*
}

\author{
Choi, Dai-Kwon ${ }^{* *}$
}

\begin{abstract}
There is a plenty of literature in which economic development is related to law ever since Max Weber had related the rise of capitalism to formal rationality of legal system. The Korea's successful rapid economic development, along with industrialization, from its economy of per capita income less than 100 dollars to that of around 20,000 dollars less than a half century later, especially its take-off stage, however, seems to put us to a puzzle in relating its experience to the rule of law. For authoritarianism is understood usually as being not friendly to the rule of law. Then the question is on how to meaningfully relate the Korean experience of economic development to law.

During its authoritarian period, korea (the Republic of Korea) might be characterized perhaps as having a dual legal structure consisting of a series of instrumental special legislations (e.g, presidential decrees, The Foreign Capital Inducement act of 1966, etc.) to support the government-led economic development policy along with the authoritarianism that was a deviation from the full-fledged rule of law and of a limited rule of law. For Korea have held its formal framework of the rule of law even during authoritarian time ever since it started as the country ordained with the liberal democratic constitution in 1948. Generally authoritarianism tends to respect autonomies of other areas than politics for the sake of its image unless its power is threatened. Consequently, the kind of legal stability and one's planning for the future that is favorable for business enterprises (savings and investment) may well be fostered even under authoritarianism, as attested with the Korean experience in the past and that of China today.
\end{abstract}

\footnotetext{
* The research for this Article was supported by the Law Research Institute at Seoul National University School of Law in 2011.

** Professor Emeritus, College of Law/School of Law, Seoul National University.
} 
It was administrative officials armed with the instrumental special legislations and with the concepts of haengjong jido, administrative guidances, to support the government-led import-substituting, export-oriented, heavy-chemical industry fostering, and other development policies, rather than lawyers involving in after-the-fact situation, who had actually led Korea's rapid industrialization and economic development. The development thus achieved has been accompanied by the waves of liberalism including the rise of the middle class, which in turn led eventually to Korea's democratization in 1987. Now along with the democratization, the gap between the written liberal democratic constitution and the authoritarian political practices is erased and a full-fledged substantive rule of law is finally obtained in Korea.

Keywords: Democratization, Authoritarianism, the Rule of Law, Instrumental Legislations, (government-led) Economic Development (growth), Industrialization, Market Economy, Legal Stability, Predictability, Farmland Reform, Saemaul Undong, Haengjong jido

\section{Introduction}

This article explores how law was meaningfully interrelated to development, particularly economic development, in the Korean context for the last half-century. Korea is known as one of the few countries in the world that successfully attained both democratization and rapid economic growth since the end of the Second World War. Gross Domestic Product (GDP) per capita in Korea was less than a hundred dollars in the 1960s, but is around twenty thousand dollars today.1) Korea has now become the world's thirteenth economic power in terms of gross domestic income.2) In only half a century, the Korean society achieved political and economic developments which took the Western world at least a few centuries to achieve.

1) 2010 Social Indicators in Korea, (Seoul: Statistics Korea, 2011), p.187, accessible at http://ecensus.go.kr; http://blog.naver.com/economyplay/14026801450. See also Young Iob Chung, South Korea in the Fast Lane: Economic Development and Capital Formation, (Oxford: Oxford University Press, 2007), p.13.

2) Chung, South Korea in the Fast Lane, p.16. 
Moreover, great strides in economic development were made from scratch during the authoritarian phase of the post-Korean War history. Subsequently, Korean democratization followed the economic development.

The central focus of this article is on the question of whether development can ever be attributed to law at all, and, if it does, in what way, with particular focus on the Korean experience. Conceptually, it is difficult to relate law to economic development. Many literatures on law and economic development tend to invariably associate the rule of law with development, ${ }^{3)}$ following in the footsteps of the Weberian proposition - the "formal-rational law" as a principal facilitating element or a prerequisite of economic development.4) The Korean experience, however, seems to repudiate such association because Korea attained leap-frog development during its authoritarian regime which appeared to contradict the rule of law. Consequently, it is necessary to analyze law and development in the context of the Korean experience. A related question is whether lawyers have ever been agents of change in the several decades of political and economic developments in Korea.

3) See David M. Trubek, "Toward a Social Theory of Law: An Essay on the Study of Law and Development," Yale Law Journal, v. 82 no. 1, 1-50 (1972); David M. Trubek, "Law and Development," in International Encyclopedia of the Social and Behavioral Sciences, 8443-46 (N. J. Smelser \& Paul B. Baltes, eds., 2001); David Kennedy, The 'Rule of Law,' Political Choices, and Development Common Sense, in David M. Trubek and Albaro Santos, eds., The New Law and Economic Development: A Critical Appraisal, (Cambridge: Cambridge University Press, 2006), pp.95-173. See generally, David M. Trubek and Marc Galanter, "Scholars in Self-Estrangement: Some Reflections on the Crisis in Law and Development Studies in the United States," Wisconsin Law Review 1974, pp.1062-1102 (1974); Douglass C. North, "Institutions, Ideology, and Economic Performance," Cato Journal, v. 11 no. 3, pp.477-488 (1992); Douglass C. North, Institutions, Institutional Change and Economic Performance, (Cambridge: Cambridge University Press, 1990); Kanishka Jayasuriya, ed., Law, Capitalism and Power in Asia: The Rule of Law and Legal Institutions, (London\&New York: Routledge, 1999); Katharina Pistor and Philip A. Wellons, The Role of Law and Legal Institutions in Asian Economic Development 1960-1995, (Oxford: Oxford University Press, 1999); Robert Brown and Alan S. Gutterman, Asian Economic and Legal Development: Uncertainty, Risk and Legal Efficiency, (London-Hague-Boston: Kluwer, 1998).

4) Cf. Alan Hunt, The Sociological Movement in Law, (London: MacMillan, 1978), pp.93-133; Sharyn L. Roach Anleu, Law and Social Change, (London: Sage, 2000), pp.21-30 (explaining that the rise of capitalism was attributable to the formal-rational law). 
Undoubtedly, law plays certain roles in any society, not only in liberal democratic societies, but also in totalitarian and authoritarian societies. For example, law played a role even in the centrally controlled command economy of Soviet Russia's totalitarian regime. But law has many senses, aspects, and elements. Then, the most relevant inquiry to explore in our intellectual enterprise is conceptually what kind, sense, aspect or element of law may be associated with political and economic development in a meaningful way. This inquiry is particularly relevant since many other factors - political, economic, social and cultural - would account for development as well, perhaps even to a greater extent.

Among other things, the rule of law must be discussed in connection with both liberal democracy and market economy herein. Theoretically, liberal democracy is impossible without the rule of law, as attested to by the liberal democratic countries of the world today. Economic development, however, can be achieved at least to a certain extent, particularly in its takeoff stage, even in a command economy like the former Soviet Union economy and under an authoritarian regime, as demonstrated by the past Korean and the present Chinese experiences. By definition, a totalitarian or an authoritarian government contradicts the rule of law. Of course, this does not mean that law plays no role in the process of economic development. Therefore, it is necessary to discern the many roles of law and various stages of the rule of law in societies, even though the terms "law" and "the rule of law" are often used interchangeably.

There are three stages of the rule of law. The first stage simply indicates any country that has law and a legal system. In fact, there is virtually no country without the rule of law, in the sense that a country in any stage of development, even if it is autocratic, has law and a legal system as indispensible institution of ruling. A country with an autocratic system would have a system of law which would be repressive and instrumental (for the authority) in its nature.5) The second

5) See Phillippe Nonet \& Philip Selznick, Law and Society in Transition: Toward Responsive Law, (New York: Harper, 1978), pp.29-52; Roberto Mangabeira Unger, Law in Modern Society: Toward a Criticism of Social Theory, (New York: Free Press, 1976), pp. $50-51$. 
stage may indicate a country whose law and legal system are autonomous from politics, religion, etc., including power-restraining legal rules and principles as their indispensible ingredients. ${ }^{6}$ ) Such legal systems include formal legal features consisting of general applicability of law, non-retroactivity, certainty, clarity, and stability. This formal legality (the formal rule of law) nurtures individual freedom ${ }^{7}$ ) and the kind of predictability and legal stability that facilitate investment and protection of property rights and contracts. ${ }^{8)}$ However, the formal rule of law may allow a country to be dictatorial. The third stage recognizes the substantive rule of law that includes justice, morality, human rights, and "higher law" ideas.9) Judicial review of legislation is an outcome of the third stage rule of law that is associated with liberal democracy. ${ }^{10)}$

The three stages of the rule of law are delineated roughly in a sequential order of development toward liberal democracy more than a contemporaneous classification. Each stage of the rule of law, however, overlaps with the other stages to a large extent. Now, with the concept of law's developmental stages in mind, an attempt will be made below to explore primarily how market-based Korean economic

6) Nonet and Selznick, Law and Society in Transition, pp.53-72; Unger, Law in Modern Society, pp.50-52.

7) See Friedrich A. Hayek, The Road to Serfdom, 50th ed., (Chicago: University of Chicago, 1994), pp.80ff.

8) See Brian Z. Tamanaha, On the Rule of Law: History, Politics, Theory, (Cambridge: Cambridge University Press, 2004), pp.91-101; see also Lon L. Fuller, The Morality of Law, rev. ed., (New Haven: Yale University Press, 1969), pp.39ff.

9) See Edward Corwin, The "Higher Law" Background of American Constitutional Law, (Ithaca: Cornell University Press, 1955); Tim Koopman, Courts and Political Institutions: A Comparative View, (Cambridge: Cambridge University Press, 2003), pp.239-245.

10) See, e.g., Dai-Kwon Choi, Honbophak Kangui (Lectures on Constitutional Law), rev. ed., (Seoul: Pakyongsa, 2001), pp.321-24; Tamanaha, On the Rule of Law, pp.102ff.; Albert Venn Dicey, An Introduction to the Study of the Law of the Constitution, 10th ed., (London: MacMillan, 1959), pp.144ff.; Donald P. Kommers, Judicial Politics in West Germany: A Study of the Federal Constitutional Court, (Beverly Hills: Sage, 1976), p.209; Christian Starck, "The Legitimacy of Constitutional Adjudication and Democracy," and Rainer Grote, "Rule of Law, Rechtsstaat and 》Etat de droit $\ll$," in Christian Starck, ed., Constitutionalism, Universalism and Democracy: A Comparative Analysis, (Baden-Baden: Nomos Verlagsgesellschaft, 1999), respectively pp.13-23 and 269-306; Koopmans, Courts and Political Institutions, pp.35-62, 63-97. 
development can be accounted for by law and how its democratization was brought about only tangentially. Along the line of this analysis, we will explore what stages of the rule of law Korea went through and how this process came about.

\section{State of Law and Economy before Takeoff}

Before discussing the law and economic development in Korea, perhaps it is necessary to briefly describe the state of law and economy Korea was situated in before the takeoff stage for the economic development in the 1960s. ${ }^{11)}$ Korea was a centralized bureaucratic country with a king as its highest authority. Its law and legal system belonged to the ancient Far Eastern law and legal system, where the Western concepts of the separation of powers, independence of the judiciary, and the role of lawyers as intermediaries between the court and the parties, were alien. Confucianism was a functional equivalent to the Western concept of constitutionalism, 12) and the codified law as such was rather a "repressive" one. Furthermore, Korea's economy was largely agricultural. The "modern" law started in Korea for the first time with the adoption of the Court Organization Act of 1895. The adoption of the "modern" law based on civil law system, however, was completed during the Japanese rule over Korea (1910 1945). Before such adoption, the Yangban (Noblemen) bureaucrats - officials dispatched from the center - acted as the governors of districts, dispensing justice as well as conducting administrative chores.

The "modern" Roman concept of ownership over land in particular began with the Japanese-conducted nationwide cadastralization: the work involving survey, investigation and registration of land,13) which started from 1911 and was completed in 1918 in

11) Dai-Kwon Choi, "Development of Law and Legal Institutions in Korea," in Bong Duck Chun, William Shaw and Dai-Kwon Choi, Traditional Korean Legal Attitudes, (Berkeley: University of California Institute of East Asian Studies, 1980), pp.54-101.

12) Choi, "Development of Law and Legal Institutions in Korea," p.71; Dai-Kwon Choi, Bopsahoehak (Sociology of Law), (Seoul: Seoul National University Press, 1983), p.63.

13) Choi, "Development of Law and Legal Institutions in Korea," p.83. 
the early stage of the Japanese rule. The forcefully conducted cadastral work, which ignored the niceties and complex variations of pre-modern land tenure mixed with official social status, turned the Korean society in a stroke into a society composed of two classes of people, namely, a small number of Japanese and Korean landlords and a large number of tenants (sharecroppers). The Japanese conduction of the cadastral work in Korea is what it would have been like if European feudal law had been replaced suddenly by the modern law without a transitional period lasting at least a few centuries. In any case, the government ran by the governor-general alone came to own a half of the entire Korean land. The existence of publicly owned lands allowed the governor-general's government to make a large number of Japanese peasants successfully settle as landlords and landowning farmers in Korea.

The Japanese laid down the characteristic features of the civil law system with the adoption of the Japanese Civil Code, the concept of judges, courts, and legal scholars in Korea. However, there was no concept of independence of the judiciary which was under the governor-general; there was no idea or institution of judicial review of governmental actions, and not even the pre-War Japanese constitution was applied to Korea. Presently, there are scholarly controversies on whether the Japanese indeed "modernized" the Korean economy or whether they simply exploited Korea more effectively; for example, the cadastralization, the laying of railways, telegraph, and telephone, and others were mainly for the benefit of Japan's more effective exploitation, not for Korean development as such. The Japanese adopted an obscurantist policy. The Japanese intentionally did not train Koreans as scientists, engineers, managers, or ranking army officers beyond the bottom-level functionaries to make them incapable of running modern industries, army and administration in a liberated country. ${ }^{14)}$ Following the Japanese surrender, in fact, enormous efforts for education and manpower training were undertaken to meet the imminent needs of the newly established free democratic nation for national security, development and many others, and to catch up to the advanced countries. In any case, the Japanese

14) Dai-Kwon Choi, "Constitutional Developments in Korea," in Review of Korean Studies, v. 6 no. 2, p.32 (2003). See also Un-kyong Pak, Iljaeha chosonin kwanryo yonku (Study on Korean Officials Under the Japanese Rule), (Seoul: Hakminsa, 1999), pp.35-39, esp.48-49. 
developed the northern part of Korea largely into a mining and heavy industrial area and the southern part into a rice and other crop-supplying area with light industries for the Japan as part of their war efforts.

Following its independence from the Japanese rule at the end of the Second World War, Korea was divided into North Korea and South Korea. North Korea developed into a Stalinist totalitarian society in its law and economic system (a centrally controlled command economy) under the aegis of the Soviet Russia's military authority since the first day of their occupation. South Korea developed, at least formally, into a liberal democratic country, under the American government's military support. At this point, the South Korean economy was largely agricultural. Until the early 1970s, the North Korean economy was known to have surpassed the South Korean economy. Now we will deal with the South Korean law and economy alone.

\section{Law and Economic Development in Korea}

(1) With the adoption of a liberal democratic Constitution in 1948, South Korea was founded under the auspices of the United Nations (UN). One of the first tasks of the Korean government was to lay down a liberal democratic foundation of law and legal system in line with the formal Constitution while eliminating the repressive former legal legacies and usages of Japan. Hence, a series of Korean codes of law, which included the Civil Code, Commercial Code, Criminal Code, and the Code of Criminal Procedure, was adopted through the 1950 s and the 1960 s to replace the former Japanese codes. Another task of first priority was to build a balanced national economy, which the Constitution formally provides for in its Chapter on Economy. Thus, the legal foundation of liberal democratic political rule and market economy was laid down at least formally in Korea.

The Farmland Reform of 1948 1949 was the epoch-making first step toward the building of a balanced national economy.15) Along with the farmland reform, the landlords and tenants classes, which were the yoke of burden on economic deve- 
lopment, disappeared from Korean society. From there, it seemed that the Korean economy began to develop. With the success of the state-led farmland reform, the state became independent from the landed interests. However, one of the reform's aims of inducing money from the landlords into capital for industry had largely failed. To a certain extent, the Korean War $(1950 \sim 1953)$ had contributed to that failure because war-time inflation rendered farmland bonds paid as compensation to landlords practically worthless. The War devastated even the meager industrial base along with the loss of human resources. Roughly speaking, the Korean economy in the $1950 \mathrm{~s}$ had sustained itself with foreign aids. Now, we move to discuss the Korean economic development from the 1960s onwards.

(2) It would be difficult to invent a single theory to explain what sparks market-oriented economic development, especially when it begins from scratch, as in the Korean case, because there are multiple variables directly and indirectly affecting economic development. ${ }^{16)}$ Korea was a war-devastated, poverty-stricken agricultural society with no accumulated capital before its economic takeoff. Per capita income was less than a hundred dollars as mentioned above. Was it the invention of new

15) For the Farm Land Reform in (South) Korea, see generally Song Chan Hong, ed., Nongjikyehyok Yonku (Studies on Farm Land Reform), (Seoul: Yonsei University Press, 2001); Song-ho Kim et al., Nongjikyehyoksa yonku (Study on Farm Land Reform History), (Seoul: Hankuk nongchonkyongje yonkuwon, 1989). The successful farmland reform in accordance with the tiller-owner principle seems to have been one of the crucial factors that differentiated Korean economic development from "dependent development" experienced in many Latin American countries and perhaps in Philippine. The factors that could account for the successful farmland reform include political necessity to meet with communist threat, the leading governmental officials' determination for farmland reform, the support of President Syngman Rhee being conscious of tillers which formed the majority of votes, among others. North Korea had already completed communized land reform known as "confiscation without compensation-free distribution" formula in 1946, threatening to do the same thing toward South Korea. The lands thus distributed to farmers in North Korea were, however, soon to be placed into collective farms. South Korea adopted confiscation with compensation-distribution with payment rule for the farmland reform.

16) See generally Robert J. Barro, Determinants of Economic Growth: A Cross-Country Empirical Study, (Cambridge: MIT Press, 1997) (discussing variables affecting economic growth). 
technology like the steam engine, Protestant ethics, ${ }^{17)}$ human beings like inventors or entrepreneurs, peoples' will to improve their lot, ${ }^{18)}$ a social movement, ${ }^{19)}$ or was it political leadership?20) What kind of role does law play, if at all, in economic development in general or in particular?

In an advanced economy, it seems that the rule of law is an indispensable element of market-oriented economic development.21) In general, those countries that have attained the substantive rule of law (whose concept includes law's power-restraining role, judicial independence, and protection of fundamental rights), or at least a formal rule of law, have an advanced economy without exception. Their rule of law particularly enhances political, social and legal stability and makes one's planning for the future easy, forming a favorable environment for business enterprises in terms of savings and investment. The formal legal features that both the formal and substantive rule of law provide clearly tend to facilitate such political, social and legal stability and predictability as seen above. It is not hard to generalize that the prevalence of arbitrary laws, which usually goes with corruption, is inimical to economic development since it makes it difficult for entrepreneurs to conduct a long-term plan and investment for the future. Corruption undoubtedly defeats legal stability and predictability. In fact, governmental anti-corruption campaign has been persistently waged with economic development drives.

The level of the rule of law that provides a favorable environment for enterprises

17) See Max Weber, The Protestant Ethic and the Spirit of Capitalism, tans. by Talcott Parsons, (New York: Charles Scribner's Son, 1958) (explaining that religious conviction provides motivation to work hard and frugally). Incidentally, Korea has the highest Christian-population ratio (a third of its population) among the three East Asian countries, Korea, China and Japan.

18) See David C. McClelland, The Achieving Society, (New York: Pree Press, 1961).

19) By relying on education, mass media, various government-led campaigns, and self-help community movements such as Saemaul Undong [New Community Movement], President Park ignited people's will to improve their lot and "we can do it" spirit is expressed in the catchphrase "Jalsarabosae" [Let us live a prosperous life].

20) See Se Hee Yoo, ed., Political Leadership and Economic Development: Korea and China, (Seoul: Hanyang University Institute for Sino-Soviet Studies, 1983).

21) See Order in the Jungle: Economics and the Rule of Law, The Economist, Mar. 13, 2008, at 83, available at http://www.ruleoflawus.info/Economy/Economics_and_the_rule_of_law.pdf. 
is attainable only in advanced liberal democratic polities, which usually exist in economically prosperous countries. Theoretically, however, a favorable environment for the exercise of entrepreneurship can also be fostered in an authoritarian or dictatorial country,22) as attested to by the case of Korea in the past and by the case of China in the present. An authoritarian country by definition does not seem to have such a concept or stage of the rule of law. Nonetheless, not all dictatorial countries have been successful in inducing economic development. Then, what differentiates those authoritarian countries that had successful economic development from other authoritarian countries that are economically impoverished?

The answer to that question may be "benevolent dictatorship." Indeed, there was an intellectual debate over the need of benevolent dictatorship in the 1960s and 1970s in Korea. The debate was on whether a benevolent dictator was necessary or tolerable for the advancement of Korea, although in the meantime Korea missed a full-fledged democracy. It has been controversial whether President Park needed the country's economic development as a justification for his dictatorial rule or whether the dictatorial rule was indeed necessary for the successful launch of the economic development program. It is true that a successful government-led economic development tends to make people think that dictatorship is tolerable or necessary to a great extent. ${ }^{23)}$ In any case, there is no doubt that President Park contributed to Korea's successful economic development.

It is probable that the leadership of benevolent dictatorship, along with its longevity, can nurture a favorable environment for enterprises by providing for a long-term socio-political stability and predictability for investment through protection

22) See Trubek, "Toward a Social Theory of Law," (hinting the possibility of authoritarianism-induced stability that could lead to economic development with Brazilian situation at pp.48-49); Stephan Haggard and Tun-jen Cheng, "State and Foreign Capital in the East Asian NICs" and Chalmers Johnson, "Political Institutions and Economic Performance: the Government-Business Relationship in Japan, South Korea, and Taiwan," in Frederic C. Deyo, ed., The Political Economy of the New Asian Industrialism, (Ithaca: Cornell University Press, 1987), respectively pp.84-135 and 136-164.

23) Probably the present Chinese situation fits closely to this statement. Interestingly, Jiang Zemin is known as having demanded the rule of morality toward the Chinese Communist Party cadres and governmental officials. 
of contract and property rights. The socio-political stability and predictability based on authoritarianism ${ }^{24}$ ) can be considered a functional equivalent to the legal stability and predictability which are provided by the rule of law that has been enjoyed by the Western liberal democratic countries. In Korea, however, the authoritarianism was practiced within the framework of the liberal democratic and market-oriented constitution, that is, a limited rule of law. There existed a plurality of political parties and a representative government, although authoritarian practices such as restrictions of press and warrantless arrest continued to take place. The economic growth and its accompanying emergence of the middle class as well as active democratic and labor movements led by liberal intellectuals, among other factors, eventually put the authoritarian practices to an end, making democratization possible in Korea.

In any case, President Park began to undertake a government-led economic development drive - consisting of setting goals and making maximum efforts to achieve those goals by authoritarian as well as non-authoritarian means, including various incentives and instrumental legislations - soon after he consolidated the power by leading the coup d'etat of 1961. The economic development drive was a market-oriented one in which policies and strategies of import-substituting and export-inducing industrialization were pursued under his personal leadership. He was an energetic CEO in organizing and leading the entire nation toward economic

24) Perhaps a limited rule of law may be possible even in authoritarianism, as seen in Korea in the past and in China today. It is characteristic of an authoritarian regime as compared with totalitarianism that autonomies are permitted in other areas than politics unless its power is threatened. An authoritarian regime is usually interested in having the semblance of the rule of law entailing predictability and stability in law and legal system to enhance its legitimacy and to control officials in line, among others, to combat corruptions. See, e.g., Tom Ginsburg, "Administrative Law and the Judicial Control of Agents in Authoritarian Regimes," Tamir Moustafa, "Law and Resistance in Authoritarian States: The Judicialization of Politics in Egypt," and Robert Barros, "Courts Out of Context: Authoritarian Sources of Judicial Failure in Chile (1973 1990) and Argentina (1976 1983)," in Tom Ginsburg and Tamir Moustafa, eds., Rule by Law: The Politics of Courts in Authoritarian Regime, (Cambridge: Cambridge University Press, 2008), respectively pp.58-72, 132-155, 156-179. The rule of law albeit a limited one probably reduces the ruling costs even in authoritarianism. 
development. For example, his catch phrase "jalsarabosae" (let us live a prosperous life) caught fire in people's heart.

At this point, it may be necessary to briefly introduce the government-led "new community movement," known as Saemaulundong, ${ }^{25)}$ which President Park initiated while he conducted the industrialization drive programs. Saemaulundong is a self-help community development movement launched to correct the imbalance between the advanced urban and industrial centers and the farming villages left behind in economic development, and to modernize the rural areas in order to achieve goals such as increase of farming income, mechanization of farming, increase of cultivated lands, improved irrigation, and improved farming houses, roads, sanitation, and water supply. The community development movement later expanded to towns and cities. Certainly the movement was instrumental nation-wide in implanting self-help and we-can-do-it spirits in the people's minds, along with the catch phrase "jalsarabosae."

In any case, President Park launched the government-led five-year economic development plan in 1962, which was followed consecutively by five other five-year plans (the Consecutive Plans). With the five-year economic development plan, he set many different goals, ranging from fixing targets for exports and imports, rapid increases of Gross National Product (GNP) (over 8\% increase per year) and per capita income, acquisition of foreign loans, construction of social overhead capitals like roads, highways, harbors, and electric plants, to betterment of rural communities. Furthermore, he personally encouraged, directed and supervised civilian entrepreneurs as well as governmental officials toward the achievement of those goals using various incentives and sanctions. He is known to have personally monitored all the statistical results of economic drives on a daily basis, reviewed reports, and conducted frequent on-the-site inspections with his ministers and aides. In total, six of the five-year economic development plans from 1962 to 199126) were achieved

25) See Saemaul Undong (New Community Movement), (Seoul: Korean Overseas Information Service, 1973) (discussing government-released descriptions of the movement); Chan Jin Kim, Economic Development and Law in Korea, (Seoul: The Catholic University of Korea Press, 2009), pp.88-99.

26) Chung, South Korea in the Fast Lane, pp.13-16. The first Economic Development Plan 
beyond his set goals and objectives.

The Korean economic development plans were directed toward the construction of export-oriented light industries (largely textile, plywood and wigs) in the 1960s, the construction of heavy-chemical industries (steel, machinery and chemicals) in the 1970s, the stabilization and development of economic democracy (along with car manufacturing and ship building industries) in the 1980s, and the advancement of neo-liberal market economy (along with semiconductor, computers and communications equipment industries) in the 1990s, punctuated by the economic crisis of 1997 1998.27) President Park died in 1979, and yet, Korea's authoritarian phase continued up to 1987 when the so-called democratization took place along with nation-wide revolt against the authoritarian government then in power. Now the gap between the formal liberal democratic constitution and the authoritarian practice has largely disappeared from the Korean socio-political scene. ${ }^{28)}$

Anti-governmental, active democratic and labor movements were undertaken to realize constitutionally-provided political and labor rights during the authoritarian period. These movements helped to align the Korean democracy with what the liberal Constitution provided for. In 1987, the Constitution was amended to incorporate direct, popular election of the President and to adopt the Constitutional Court, among others. The people's freedom has been definitely expanded along with further progress of the rule of law.

(3) During the period of the government-led economic development drive from 1962 undertaken with the Consecutive Plans, a large number of special legislations were adopted in order to support the economic development drive and to stimulate

(1962 66), the second Plan $(1967 \sim 71)$, the third Plan $(1972 \sim 81)$, the fourth Plan (1977 81), the fifth Plan (1982-86) and the sixth Plan (1987 91) make up the total six consecutive economic development plans undertaken by the Korean government with the goals and objectives to achieve and the policy implementation tools.

27) Chung, South Korea in the Fast Lane, pp.84-90.

28) See Choi, "Constitutional Developments in Korea," pp.34-37; Dai-Kwon Choi, "Legal Profession in Transformation: the Korean Experience," in William L.F. Felstiner, ed., Reorganization and Resistance: Legal Professions Confront a Changing World, (Oxford/ Portland: Hart, 2005), pp.180-186. 
the growth of private sector industries. These special legislations may be characterized largely as "instrumental" law. ${ }^{29)}$ These instrumental legislations provided for various incentives including tax exemptions, ${ }^{30)}$ guaranteed remittance, ${ }^{31)}$ subsidies, citations, and rewards of funds to the entrepreneurs who were performing well in manufacturing and exportation. They also provided for varieties of sanctions including forfeitures of incentives, retractions of permits, and licenses. The Consecutive Plans with their support certainly helped to bring about rapid economic development in Korea.

Here we can visualize two sets of laws during the period of government-led economic development drive: the instrumental law in the form of special legislations, which were also associated with the authoritarian practices such as suppression of democratic and labor rights and freedom; and the formal liberal democratic law in the form of the written Constitution and the set of Codes (including the Civil Code, Commercial Code, Criminal Code, Civil Procedure Code, and Criminal Procedure Code) that were laid down to form the very foundation of the rule of law and the market.

In the legal process, the instrumental special legislations were addressed primarily to government officials in charge of policy implementation in the economic development drive to deal with before-the-fact situations such as permits, licenses, and provisions of incentives for business activities. ${ }^{32}$ ) The foundational rule of law

29) See for the history of such instrumental legislations, e.g., Sang Young Lee, Hankuk kyongjaesongjang kwa kyongjaekwankyebop (The Relationship of Economy-Related Law with the Economic Growth in Korea), Master of Law Theses, Seoul National University, (1986); see also Sang Young Lee, "Haebanghu hankukbopjae byonchonsa" (Korean History of Legislation Changes), Bopjae Yonku (Legislation Research), v. 14, pp.79-109 (1998).

30) E.g., Foreign Capital Inducement Act (1966), arts. 15 and 21, available at http://www.law. go.kr/lsSc.do?menuId $=0 \& \mathrm{p} 1=\&$ subMenu $=2 \&$ query $=\% \mathrm{EC} \% 99 \% \mathrm{~B} 8 \% \mathrm{EC} \% 9 \mathrm{E} \% 90 \% \mathrm{~EB} \% 8 \mathrm{~F} \%$ $84 \% \mathrm{EC} \% 9 \mathrm{E} \% 85 \% \mathrm{~EB} \% \mathrm{~B} 2 \% 95 \& \mathrm{x}=27 \& \mathrm{y}=14 \#$ liBgcolor 1 .

31) E.g., Foreign Capital Inducement Act (1966) arts. 22 and the following.

32) The special instrumental legislations are basically regulatory administrative laws in their nature. Their provisions for permits, licenses, incentives for business activities, and others are de facto enabling clauses for the exercise of haengjong jido, which does not carry a legally binding force but power of influence as will be introduced shortly. See infra note 36 . 
matters, the written Constitution and the Civil Code, etc., are more for after-the-fact situations involving the courts and judges to deal with protection of property rights and contracts and with damages, and so forth. The formal rule of law was there indeed in the background. But it was goal-oriented government officials armed with the special legislation-provided instruments, rather than judges and lawyers, who had primarily helped to move people to engage in industrial activities. It is first of all because Korea simply had no capital, no skill and no technology in the early stage of economic development.

In any case, the existence of the formal legality differentiates Korea at that time from China today because China does not have a liberal constitution providing for party pluralism, freedom of speech and other human rights. China has only recently begun to adopt civil law (property law) and other laws that are essential for market economy, but not politically liberal law for pluralism and freedom of speech. The formal liberal democratic law had a profound educational impact on Koreans, especially on students and intellectuals. Even governmental authoritarian practices had the reverse impact of making Koreans confirm their liberal conviction in their hearts. Anti-authoritarian democratic and labor movements took the form of activists claiming human and labor rights provided in the written Constitution.

Rapid economic developments accompanied by industrialization brought about enormous social changes including a large scale rural emigration, urbanization, social complexity, globalization, and emergence of large scale organizations such as business firms, press, political parties, and labor unions. ${ }^{33)}$ Among other social changes, the emergence of the middle class and intellectuals stood out in the socio-political scene, having liberal impacts on politics and social processes. To a great extent, this emergence contributed to the fall of the authoritarian regime and the rise of the substantive rule of law in Korea.34)

The same social changes that were brought about by industrialization and economic growth had now made economic and social environments too complex for economic actors like business firms and investors so that bureaucratic governmental

33) See Choi, "A Legal Profession in Transformation," p.179.

34) See Choi, "Constitutional Developments in Korea," pp.34-37 (as cited above). 
directions and regulations were no longer efficient. The voices to the effect that business activities should be subject to the market, not to governmental directions and regulations, began to be loudly heard along with neo-liberalism. Probably the economic crisis of 1997 1998, which is remembered by Koreans as "the International Monetary Fund (IMF) crisis" involving bailout loans from the IMF, made such conviction firm and strong. Now the economic development in Korea's globalized economy is very much up to entrepreneurship and invisible market forces supported by the enhanced rule of law rather than governmental directions and regulations. Elimination or reduction of governmental regulations and combat against corruption are today's catchphrases in the Korean government. Transparency, restructuring, and bans on slush money became the guiding rules and doctrines of business firms in private sectors, particularly after the economic crisis of 1997 1998.

Not only the market forces but also social pluralism, in the sense that there emerged plural groups, organizations, social strata and classes, and even labormanagement relations, have made the rule of law inevitable and necessary. Because no one group or class alone can dominate or dictate others in the political, social and economic scenes any longer, people must resort to the rule of law. Also, the activism of the Constitutional Court has contributed to the expansion of the rule of law in Korean society to a great extent. ${ }^{35)}$

At this point of our discussion, an analysis of the concept of haengjong jido (administrative guidance) ${ }^{36}$ ) is in order. The haengjong jido is not a legal term involving legal force, but the concept appears in every Korean administrative law textbook because it played a very important role in administrative practices. The concept has a firm position in Japan's administration as well. Along with the instrumental special legislations, the haengjong jido played particularly an important role in the economic development drive described above. A haengjong jido issued by

35) Dai-Kwon Choi, "Minjujuuiwa bopchijuui: honbopjaepanui jongchihak" (Democracy and the Rule of Law: The Politics of Constitutional Adjudication), Honbop ronchong (Constitutional Law Journal) (the Korean Constitutional Court), v. 19, pp.177-223 (2008).

36) For the concept of haengjong jido, see Do Chang Kim, Ilban haengjongbopron (General Theory of Administrative Law), v. 1, 3rd. rev. ed., (Seoul: Chongunsa, 1988), pp.479-384. 
a public official toward economic actors does not have a legally binding effect since it is simply an official's guidance or advice toward those who plan to invest, apply for foreign loans, build a business office, or place a price. However, those who refuse to respect such an advice or guidance might face various forms of adverse reactions from the officials such as refusal of extension of permits or denial of licenses.37) The haengjong jido used to be effective in the era of the government-led economic development drive. But it is no longer effective along with the rule of law, and it is also inefficient in the complex market situation. Now the government has only a limited leverage over the market. The rule of law is now firmly in place, although it remains to be further matured.

\section{Concluding Remarks}

The government-induced rapid economic development in Korea during the 1960s, 1970s, and up to the mid-1980s is definitely a deviation from the Western idea that associates development invariably with the rule of law and with market economy since those years are recorded as the authoritarian period that threatened the rule of law. Indeed, certain aspects of the rule of law such as freedom of speech and assembly as well as labor rights were denied constitutionally provided protection, and judicial independence was often compromised. Political expediency in the name of governmental economic development drive (such as government-provided incentives) prevailed over market rules of competition in certain sectors such as importsubstituting, export-oriented, and heavy industries. Labor wages were also suppressed to make Korean products have a competitive edge in foreign markets. However, the formal liberal democratic and market oriented constitution was basically there. Thus, Koreans had experienced a gap between those authoritarian political practices and the formal law. The full-fledged rule of law (i.e., the substantive rule of law) was compromised accordingly. Instead, what prevailed was a limited rule of law (i.e., the

37) Kim, Ilban haengjongbopron, pp.482-83. 
formal rule of law).

The very existence of liberal democratic constitution itself had educational impacts on citizens, especially on intellectuals and students in many ways. In fact, active anti-authoritarian democratic movements were undertaken in the name of realizing the constitutionally provided fundamental rights including labor rights and democratic ideals. The government-led economic development drive was made to foster self-sustaining market economy in Korea and to strengthen it.

Eventually, economic growth and democratization filled the gap, making Koreans live up to the formal constitutionally-promised rule of law, concomitant liberal democracy, and economic prosperity to a great extent. During the years of the economic development drive, the public government officials, rather than the lawyers, played a role in the change. One of the tools which the public officials readily used during those drive years included the haengjong jido, the administrative guidance. Today, however, the lawyers are coming to the forefront to serve the globalized economic activities. ${ }^{38)}$ Large law firms are mushrooming in Korea. ${ }^{39)}$ The methods of administrative guidance proved to be inefficient, and reduction or abolition of regulations are today's catchphrases. The Constitutional Court has been very active in protecting the human rights and freedom as well as the Constitution. Maturity in the rule of law and democratic rule is now the norm for Korean society to attain.

A final comment is related to the performance of China's so-called "socialist market economy." China has been doing excellent in developing its own economy under the one-party rule. However, the Chinese economic development would inevitably bring about enormous social changes in which middle class and intellectuals emerge, with liberalizing impacts on their country's politics and society.

38) See Choi, "A Legal Profession in transformation," pp.179-186.

39) See Kuk Woon Lee, "Corporate Lawyers in Korea: An Analysis of the 'Big 4' Law Firms in Seoul," in Dai-Kwon Choi \& Kahei Rokumoto, eds., Judicial System Transformation in the Globalizing World: Korea and Japan, (Seoul: Seoul National University Press, 2007), pp.219-250. 
56 『서울대학교 法學』제52권 제 3 호 (2011.9.)

I am curious as an intellectual observer as to whether China's one-party rule, the suppression of political rights and freedom, and the lack of the rule of law would ultimately survive the liberalizing impacts of economic development, the accompanying social changes and the emergence of the middle class. In the meantime, I am also observing the rule of law steadily growing in China adopting property law and other market-demanded legislations, albeit not politically and religiously liberalizing. 40 )

투고일 2011. 7. 25 심사완료일 2011.9.6 게재확정일 2011.9.8

40) See Randall Peerenboom, China's Long March toward Rule of Law, (Cambridge: Cambridge University Press, 2002). 


\section{BIBLIOGRAPHY}

Anleu, Sharyn L. Roach, Law and Social Change, (London: Sage, 2000).

Barro, Robert J. Determinants of Economic Growth: A Cross-Country Empirical Study, (Cambridge: MIT Press, 1997).

Barros, Robert, "Courts Out of Context: Authoritarian Sources of Judicial Failure in Chile (1973-1990) and Argentina (1976-1983)," in Tom Ginsburg and Tamir Moustafa, eds., Rule by Law: The Politics of Courts in Authoritarian Regime, (Cambridge: Cambridge University Press, 2008).

Brown, Robert and Alan S. Gutterman, Asian Economic and Legal Development: Uncertainty, Risk and Legal Efficiency, (London-Hague-Boston: Kluwer, 1998).

Choi, Dai-Kwon, Bopsahoehak (Sociology of Law), (Seoul: Seoul National University Press, 1983).

, "Development of Law and Legal Institutions in Korea," in Bong Duck Chun, William Shaw and Dai-Kwon Choi, Traditional Korean Legal Attitudes, (Berkeley: University of California Institute of East Asian Studies, 1980), pp.54-101.

, Honbophak Kangui (Lectures on Constitutional Law), rev. ed., (Seoul: Pakyongsa, 2001).

, "Constitutional Developments in Korea," Review of Korean Studies, v.6 no.2, pp.27-48 (2003).

, "Legal Profession in Transformation: the Korean Experience," in William L.F. Felstiner, ed., Reorganization and Resistance: Legal Professions Confront a Changing World, (Oxford/Portland: Hart, 2005), pp.171-194. , "Minjujuuiwa bopchijuui: honbopjaepanui jongchihak" (Democracy and the Rule of Law: The Politics of Constitutional Adjudication), Honbop ronchong (Constitutional Law Journal) (the Korean Constitutional Court), v. 19, pp.177-223 (2008).

Choi, Dai-Kwon \& Kahei Rokumoto, eds., Judicial System Transformation in the Globalizing World: Korea and Japan, (Seoul: Seoul National University 
Press, 2007).

Corwin, Edward, The "Higher Law" Background of American Constitutional Law, (Ithaca: Cornell University Press, 1955).

Chung, Young Iob, South Korea in the Fast Lane: Economic Development and Capital Formation, (Oxford: Oxford University Press, 2007).

Deyo, Frederic C. ed., The Political Economy of the New Asian Industrialism, (Ithaca: Cornell University Press, 1987).

Dicey, Albert Venn, An Introduction to the Study of the Law of the Constitution, 10th ed., (London: MacMillan, 1959).

Fuller, Lon L. The Morality of Law, rev. ed., (New Haven: Yale University Press, 1969).

Hayek, Friedrich A. The Road to Serfdom, 50th ed., (Chicago: University of Chicago, 1994).

Ginsburg, Tom, "Administrative Law and the Judicial Control of Agents in Authoritarian Regimes," in Tom Ginsburg and Tamir Moustafa, eds., Rule by Law: The Politics of Courts in Authoritarian Regime, (Cambridge: Cambridge University Press, 2008).

Ginsburg, Tom and Tamir Moustafa, eds., Rule by Law: The Politics of Courts in Authoritarian Regime, (Cambridge: Cambridge University Press, 2008).

Grote, Rainer, "Rule of Law, Rechtsstaat and 》Etat de droit $\ll$," in Christian Starck, ed., Constitutionalism, Universalism and Democracy: A Comparative Analysis, (BadenBaden: Nomos Verlagsgesellschaft, 1999).

Haggard, Stephan and Tun-jen Cheng, "State and Foreign Capital in the East Asian NICs," in Frederic C. Deyo, ed., The Political Economy of the New Asian Industrialism, (Ithaca: Cornell University Press, 1987).

Hong, Song Chan, ed., Nongjikyehyok Yonku (Studies on Farm Land Reform), (Seoul: Yonsei University Press, 2001).

Hunt, Alan, The Sociological Movement in Law, (London: MacMillan, 1978).

Jayasuriya, Kanishka, ed., Law, Capitalism and Power in Asia: The Rule of Law and Legal Institutions, (London\&New York: Routledge, 1999).

Johnson, Chalmers, "Political Institutions and Economic Performance: the Government- 
Business Relationship in Japan, South Korea, and Taiwan,” in Frederic C.

Deyo, ed., The Political Economy of the New Asian Industrialism, (Ithaca:

Cornell University Press, 1987).

Kim, Chan Jin, Economic Development and Law in Korea, (Seoul: The Catholic University of Korea Press, 2009).

Kim, Do Chang, Ilban haengjongbopron (General Theory of Administrative Law), v. 1, 3rd. rev. ed., (Seoul: Chongunsa, 1988).

Kim, Song-ho et al., Nongjikyehyoksa yonku (Study on Farm Land Reform History), (Seoul: Hankuk nongchonkyongje yonkuwon, 1989).

Kommers, Donald P. Judicial Politics in West Germany: A Study of the Federal Constitutional Court, (Beverly Hills: Sage, 1976).

Koopman, Tim, Courts and Political Institutions: A Comparative View, (Cambridge: Cambridge University Press, 2003).

Kennedy, David, The 'Rule of Law', Political Choices, and Development Common Sense, in David M. Trubek and Albaro Santos, eds., The New Law and Economic Development: A Critical Appraisal, (Cambridge: Cambridge University Press, 2006).

Lee, Kuk Woon, “Corporate Lawyers in Korea: An Analysis of the 'Big 4' Law Firms in Seoul," in Dai-Kwon Choi \& Kahei Rokumoto, eds., Judicial System Transformation in the Globalizing World: Korea and Japan, (Seoul: Seoul National University Press, 2007).

Lee, Sang Young, "Haebanghu hankukbopjae byonchonsa" (Korean History of Legislation Changes), Bopjae Yonku (Legislation Research), v. 14, pp.79-109 (1998). , Hankuk kyongjaesongjang kwa kyongjaekwankyebop (The Relationship of Economy-Related Law with the Economic Growth in Korea), Master of Law Theses, Seoul National University, (1986).

McClelland, David C., The Achieving Society, (New York: Pree Press, 1961).

Moustafa, Tamir, "Law and Resistance in Authoritarian States: The Judicialization of Politics in Egypt," in Tom Ginsburg and Tamir Moustafa, eds., Rule by Law: The Politics of Courts in Authoritarian Regime, (Cambridge: Cambridge 
University Press, 2008).

Nonet, Phillippe \& Philip Selznick, Law and Society in Transition: Toward Responsive Law, (New York: Harper, 1978).

North, Douglass C. Institutions, Institutional Change and Economic Performance, (Cambridge: Cambridge University Press, 1990). , "Institutions, Ideology, and Economic Performance," Cato Journal, v. 11 no. 3, pp.477-488 (1992).

Pak, Un-kyong, Iljaeha chosonin kwanryo yonku (Study on Korean Officials Under the Japanese Rule), (Seoul: Hakminsa, 1999).

Pistor, Katharina and Philip A. Wellons, The Role of Law and Legal Institutions in Asian Economic Development 1960-1995, (Oxford: Oxford University Press, 1999).

Saemaul Undong (New Community Movement), (Seoul: Korean Overseas Information Service, 1973).

Starck, Christian, "The Legitimacy of Constitutional Adjudication and Democracy," in Christian Starck, ed., Constitutionalism, Universalism and Democracy: A Comparative Analysis, (Baden-Baden: Nomos Verlagsgesellschaft, 1999).

Starck, Christian, ed., Constitutionalism, Universalism and Democracy: A Comparative Analysis, (Baden-Baden: Nomos Verlagsgesellschaft, 1999).

Tamanaha, Brian Z. On the Rule of Law: History, Politics, Theory, (Cambridge: Cambridge University Press, 2004).

Trubek, David M. "Law and Development," in International Encyclopedia of the Social and Behavioral Sciences, 8443-46 (N. J. Smelser \& Paul B. Baltes, eds., 2001).

, "Toward a Social Theory of Law: An Essay on the Study of Law and Development," Yale Law Journal, v. 82 no. 1, 1-50 (1972).

Trubek, David M. and Marc Galanter, "Scholars in Self-Estrangement: Some Reflections on the Crisis in Law and Development Studies in the United States," Wisconsin Law Review 1974, pp.1062-1102 (1974).

Trubek, David M. and Albaro Santos, eds., The New Law and Economic Development: A Critical Appraisal, (Cambridge: Cambridge University Press, 
2006).

Unger, Roberto Mangabeira, Law in Modern Society: Toward a Criticism of Social Theory, (New York: Free Press, 1976).

Weber, Max, The Protestant Ethic and the Spirit of Capitalism, tans. by Talcott Parsons, (New York: Charles Scribner's Son, 1958).

Yoo, Se Hee, ed., Political Leadership and Economic Development: Korea and China, (Seoul: Hanyang University Institute for Sino-Soviet Studies, 1983). 
<국문요약>

\section{Law \& Development*}

\section{崔大 權 ${ }^{* *}$}

Max Weber가 법체제의 형식적 합리성을 경제성장과 관련시킨 이래로 법치주의 와 경제성장을 연계시키는 서양문헌이 많다. 1 인당 국민소득이 100 달러도 안되던 우리나라가 반세기도 안되는 기간에 산업화와 함께 2만달러에 이른 빠른 성공적 경제성장은, 특히 그 도약단계가 권위주의시대에 이루어진 우리의 경험은 법치주 의와 연계시키는 일을 일응 곤혹스럽게 만든다. 권위주의는 법치주의와 친하지 아 니한 것으로 이해되고 있기 때문이다. 그렇다면 우리의 경제성장의 경험을 법과 어떻게 유의미하게 연계시킬 수 있을 것인가?

대한민국은 1948 년에 자유민주주의의 헌법질서를 가진 나라로 출발하여 법치주 의의 틀을 지니고 있었기 때문에 권위주의시대에 이르러 이 법치주의로부터 이탈 한 권위주의와 함께 정부주도의 경제성장정책을 뒷받침하는 수단으로의 법(예컨대 긴급조치, 1966년의 외자도입법 등)과 한정된 법치주의의 이중적 법구조를 지녔다. 권위주의는 정치권력에 도전하지 아니하는 한 자신의 이미지를 위해서도 여타의 영역의 자율(법치주의)을 존중하는 모습을 보이는데 관심을 지니는 특징을 지닌다. 그리하여 권위주의도 시장경제에 바탕을 둔 경제성장(예컨대 투자)에 유리한 법적 안정성과 예측가능성을 보여줄 수 있다. 과거의 우리나라와 지금의 중국이 이를 보여주고 있는 것이다.

우리의 권위주의시대에, 사후적으로 관여하게 마련인 법률가가 아니라, 정부주 도의 수입대체·수출주도의 산업화정책, 중화학공업육성정책 등을 뒷받침한 일련 의 수단으로서의 특별경제입법의 틀 위에 행정지도의 개념으로 무장한 경제부처 행정공무원이 우리의 급속한 산업화와 경제성장을 이끌었다고 말할 수 있다. 이렇 게 하여 이룩한 경제성장은 이와 함께 중산충의 성장을 비롯한 자유화의 물결을 가져와 결국 민주화(1987)를 이룩하기에 이르렀다. 민주화로 인하여 우리나라 자 유민주주의의 성문헌법과 권위주의 정치현실의 갭이 메워지게 되었으며 이제 제대 로 된 (실질적)법치주의를 지니게 되었다.

* 이 논문은 서울대학교 법학발전재단 출연 법학연구소 기금의 2011학년도 학술연구비 지원을 받았음.

** 서울대학교 법과대학/법학대학원 명예교수. 